\title{
A Primer on Exporting to Suriname ${ }^{1}$
}

\author{
Christina D. Storz, Timothy G. Taylor, and Gary F. Fairchild ${ }^{2}$
}

\section{Introduction}

Every year the U.S. Department of State publishes extensive Country Commercial Guides for a large number of countries. These guides provide a great deal of information useful to individuals interested in developing export markets either through direct exports or through direct foreign investment. This paper provides an abridged version of the Country Commercial Guide for Suriname as well as supplemental information of direct relevance to agribusiness firms. It is hoped that the information contained in this report provides a useful starting point for individuals interested in exploring export or investment opportunities in Suriname.

Note: County Commercial Guides are available for U.S. exporters from the National Trade Data Bank's CD-ROM or via the Internet. Please contact Stat-USA by telephone (1-800) STAT-USA for more information. Country Commercial Guides can be accessed via the World Wide Web at http://www.stat-usa.gov, http://www.state.gov, and http://www.mac.doc.gov. They can also be ordered as a hard copy or on diskette from the National Technical Information Service (NTIS) by telephone (1-800) 553-NTIS. American exporters seeking general export information/assistance and country-specific commercial information should contact the U.S. Department of Commerce, Trade Information Center by telephone (1-800) USA-TRADE; or by fax (202) 482-4473.

\section{Economic and Political Overview}

Suriname is a natural-resource wealthy country, covering an area slightly larger than the state of Georgia, of which $90 \%$ is rain forest. Its approximately 440,000 people are of mainly East Indian, African, Indonesian, Chinese, and European descent. Imports account for more than $80 \%$ of consumption in Suriname and come mostly from Europe and North America. The United States is Suriname's most important trading partner. In 2001, U.S. exports to Suriname totaled US $\$ 158.3$ million, dropping to US\$75 million in 2002.

Products from the United States and the Caribbean Region, especially consumer goods and foodstuffs, are gradually replacing traditional imports from Europe; a trend that accelerated as a result of Suriname's entry into CARICOM and expressed desire to integrate more closely regionally. Foreign competition comes from European exporters, largely Dutch firms; Asian suppliers; and exporters from the region (Trinidad and Tobago, and Brazil).

1. This is EDIS document FE522, a publication of the Department of Food and Resource Economics, Florida Cooperative Extension Service, Institute of Food and Agricultural Sciences, University of Florida, Gainesville, FL. Published February 2005. Please visit the EDIS website at http://edis.ifas.ufl.edu.

2. Christina D. Storz, Research Assistant; Timothy G. Taylor, Professor; and Gary F. Fairchild, Professor, Department of Food and Resource Economics, Florida Cooperative Extension Service, Institute of Food and Agricultural Sciences, University of Florida, Gainesville, FL. 
Although it has been rated as one of the top 20 countries with the most natural resources, Suriname's natural resource sector remains under-developed. Current opportunities in this sector include oil, gold, kaolin, building/decorative stone mining, wood harvesting and processing, limited eco-tourism, shrimp, fishing, agriculture (e.g., rice and bananas). The majority of concessions that the government has granted are for timber and mining.

Despite the number of investment opportunities available in Suriname, investment risks remain. New laws are being developed to modernize Suriname's financial and business sectors, but progress is slow. Meanwhile, many regulations and business norms taken for granted in the United States are not in place in Suriname, or are not enforced. Favoritism, especially for the political/ethnic/business elite, remains common in business and government. Most foreign businesses working in Suriname rely on a prominent local business partner to maneuver through numerous trade and investment rules. Persisting shortages of foreign exchange occasionally distort the financial environment, exacerbating international fund transfer problems. The banking and financial sectors are still closely regulated, although regulations have been loosened in recent months. Licensing requirements remain cumbersome even though the government has been moving slowly to liberalize the process. Finally, bureaucratic delays and red tape are a constant irritation to foreign investors. A new investment law calls for a "one-stop window" for business facilitation, but it has yet to be implemented by the Ministry of Internal Affairs.

Natural resource development is a promising growth area. Foreign companies, often under joint venture agreements with Surinamese firms, have made new investments in gold mining, oil, and wood harvesting and processing. Surinamese companies are beginning to invest in small-scale eco-tourism, but industry growth has been inhibited by Suriname's lack of infrastructure. Traditional exports to CARICOM and the European Union market could be promising sectors for growth, given Suriname's close relationship to these markets. Such exports might include beef, bananas, flowers, and fresh vegetables.
There are many opportunities offered by Suriname's move to privatization. In 1999 , government privatized the Suriname Alcohol Company, selling controlling interest in the company to the Trinidadian company Angostura. The government is reportedly considering privatization of some of its other companies, several of which are heavily in debt. However, no progress has been reported on the search for potential investors for any other government-owned company.

\section{Marketing U.S. Products and Services}

There are a number of factors that should be considered in exporting products to Suriname. This section provides a brief overview of many critical factors that must be considered.

\section{Establishing a Business}

Individual businessmen, corporations and other businesses are obliged to register their business and trade name at the Surinamese Chamber of Commerce (KKF).

\section{Agents / Distributors: Finding a Partner}

The Surinamese Chamber of Commerce (KKF) can help locate local distributors. A local distributor remains the best means to enter the Surinamese market. As the market is relatively small, most foreign exporters resort to building relationships with retail firms rather than establishing a distribution system.

\section{Franchising}

American franchising has had early success since starting in Suriname in 1996. From the first U.S. franchise, KFC (opened in Paramaribo in 1996), the market has grown to include Pizza Hut, McDonald's, Popeye's, Power Smoothie, and Western Union. A number of Caribbean and European franchises also operate in Suriname.

\section{Joint Ventures / Licensing}

Joint ventures with foreign companies and productions under license are permitted under Surinamese law and are being encouraged by the 
current government. There are several operations of both types in Suriname, and there is increasing interest by local entrepreneurs in manufacturing licensing arrangements.

\section{Advertising / Trade Promotion}

Surinamese advertising is direct and inexpensive. There are three daily newspapers: de Ware Tijd, de West, and Dagblad Suriname, all of which are Dutch-language. There are many AM and FM radio stations and 10 television stations. All accept commercial advertising. In addition, there are several advertising agencies. There are two annual trade fairs of significance: ITIFAS (a showcase for Surinamese producers) in October and Suri-Flora (a horticultural/ agricultural exhibition) in April. Both shows have grown considerably over the last few years. The Surinamese Chamber of Commerce (KKF) is interested in expanding the size and number of local trade-shows. The Embassy also sponsors a yearly "Made in the USA" trade show in July. Companies interested in these fairs should contact the U.S. Embassy in Paramaraibo or the Surinamese Chamber of Commerce (KKF).

\section{Sales Service / Customer Support}

There is little protection of consumers in Suriname, although the government does ensure that businesses adhere to price controls and attempts to ensure food is not sold beyond its expiration date.

\section{Product Pricing}

Price controls remain on a few consumption goods. In addition, there is an old law still on the books that makes overpricing of goods illegal. However, this law is only rarely enforced in cases where prices are truly excessive.

\section{Selling to the Government}

There is no government procurement system. Surinamese government-contracting regulations, called the "Algemene Bepaling van Suriname" (General Guidelines for Suriname-ABS), cover contract work and services. Government procurement of goods, equipment, and supplies, however, is not subject to regulation, and procedures are often irregular. Many large-scale government contracts are funded by aid grants, which restrict competition from outside bidders.

Potential government-contract bidders must be licensed to operate a business in Suriname. As the licensing process is complex, foreign companies usually form partnerships with licensed local firms to bid on government contracts.

\section{Need for a Local Attorney}

In general, routine export transactions should not require an attorney. However, for contract negotiations or dispute settlements, it may be wise to retain a local attorney, since Surinamese law is based on the Napoleonic Code and differs substantially from U.S. common law.

\section{Agribusiness Industry Prospects}

In July of 1995, Suriname became eligible under the US\$70 million Eastern Caribbean Regional program for the U.S. Department of Agriculture's Commodity Credit Corporation Export-credit Financing Program (GSM-102). Approved commodities are dairy products (non-fat or whole milk powder), barley malt, feed grains, oilseeds, poultry breeder stock, protein meals, rice, vegetable oils, wheat, wood and wood products, tallow, lard, and $100 \%$ cotton yarn and fabrics. The Surinamese importer is required to open a letter of credit with an approved Caribbean Bank. For additional information on the GSM-102 program, please contact the U.S. Department of Agriculture's Foreign Agricultural Service or the U.S. Embassy in Paramaraibo.

\section{Processed Foods}

Surinamese consumers have Western tastes and the demand for processed foods has remained steady over the past few years. Surinamers appear to appreciate the quality and price of U.S. goods. Most processed foods are imported from Europe (mainly the Netherlands), the United States, and CARICOM. However, they are often expensive and close to the expiration date. Producers of quality, moderately-priced canned goods, cookies, snacks, and frozen foods may find a ready market for their products. A local importer is successfully distributing American ice cream. 


\section{Agro-Industry / Fisheries}

The government is interested in promoting the expansion of animal husbandry with the goal of capturing the CARICOM market. Vegetables have also been identified as an opportunity area for export to CARICOM. Additionally, Suriname's coastal agricultural areas may provide opportunities for agribusiness investments (e.g., rice, palm oil, and fruit). Suriname's wild-harvested shrimp are exported primarily to Japan, with some going to the United States. Opportunities currently exist for fresh-catch seafood and aquaculture. Two small-scale aquaculture enterprises are operational.

\section{Trade Regulations and Standards}

\section{Customs Valuation}

In July of 1994, the Surinamese government adjusted the exchange rate at which imports are valued for Customs purposes to a unified, set exchange rate. As of 2002, the official exchange rate is SF 2650 per one U.S. dollar for selling and SF 2600 for purchasing.

\section{Labeling Requirements}

Products must be clearly labeled, with the content, weight, brand, production date, and expiration date of the product clearly visible. This may be done in English.

\section{Temporary Entry Provisions}

Temporary entry is not generally applicable in Suriname. With the exception of re-export of goods to Guyana and illegal smuggling to French Guyana, Suriname is not a distribution point for shipping or air cargo. Nonetheless, temporary entry under bond can be arranged.

\section{Import Controls}

There are two special import taxes: the statistics duty, which is $0.5 \%$ (one-half of one percent) of a product's value, and the consent duty, which is $1.5 \%$ (one and one-half percent) of a product's value.

Import tariffs from non-CARICOM products range between $0 \%$ and $40 \%$. According to the
Ministry of Trade and Industry officials, average import duties are between $30 \%$ and $40 \%$. Licenses are no longer required to import many products.

Import licenses are no longer required for all imports; however, the local importer must register with the Ministry of Trade and Industry and pay a small fee. The government has announced its intention to establish a "one-stop-shop" for licenses and permits. To import certain goods (e.g., plants and animals), licenses and certifications are required from other ministries.

An obsolete trade law implemented during the military regime in the 1980s prohibited imports of hundreds of goods. According to the Ministry of Trade and Industry, this law has been discontinued.

\section{Export Controls}

Suriname has minor export controls. A list of goods that are prohibited for export is available from the Ministry of Trade and Industry. A number of products require export licenses that must be approved by the Ministry of Trade and Industry's department of business licenses.

\section{Membership in Free Trade Agreements}

Suriname officially became a full member of the Caribbean Common Market on July 4, 1995. Suriname eliminated tariffs on CARICOM products on January 1, 1996, and fully adheres to CARICOM's common external tariff regime (with most rates in the $5 \%$ to $25 \%$ range). CARICOM membership is increasing Suriname's regional economic activity. The Surinamese government regards CARICOM membership as an important stepping-stone toward a Free Trade Area of the Americas (FTAA) agreement.

Suriname is also a member of the Amazon Charter with Brazil, and the Association of Caribbean Producers.

\section{Investment Climate in Brief}

- Ministers and other Surinamese government officials repeatedly voice their support for liberalization and economic reform. There is slow but steady progress being made to remove subsidies and to liberalize the economy. 
Suriname has responded by welcoming investment initiatives, and is slowly pressing forward toward a simplified, more transparent trade law and investment law that provide for dispute settlements, and investment initiatives and national treatment.

- In general, foreign investors and exporters are expected to maintain a higher standard of good business practices than Surinamese firms. While Surinamese companies might escape with bending the rules, foreign companies are generally held to the letter of the law and discovered infractions are widely publicized. Large segments of Surinamese society retain a nationalistic suspicion of foreign investors.

- Currently, most foreign exchange is based on the market rate, although some companies' contracts with the government may require that they use the official rate.

- Partially as a result of the decreased value of the guilder, which encourages locals use dollars for their most important transactions, foreign exchange reserves are limited.

- The Embassy is unaware of any cases of expropriation in Suriname.

- There have been no major investment disputes since 1990.

- While urban crime is on the rise and incidences of banditry and armed robbery in the interior, foreign investors or investments have not been specifically targeted. Isolated incidents of political violence cannot be completely ruled out. The likelihood that such actions would target foreign investments is small.

- Although the Surinamese government provides investment incentives to domestic investors, including long-term land leases, factory space, preferential credit, and tax holidays, little use has been made of the incentives. Current practice is for foreign investors to negotiate unique investment-incentive packages agreeable to the government and/or local partners.
- Suriname is a party to the Paris Convention and the Berne Convention. Trademarks receive adequate protection, but otherwise there is generally little protection against intellectual property rights (IPR) infringement.

- The law accords property ownership as a basic right in Suriname, reserved only for Surinamese citizens, and guaranteed by the Constitution; however, in practice, there are few property owners. Generally, land and natural resources are considered the patrimony of the state, which grants leases of varying duration to private enterprises.

- Surinamese law provides for the right of an individual or company to hold land, buildings and equipment. Settlement of ownership disputes or damage to property, buildings, or equipment can be an extremely lengthy process in the undermanned, overworked, legal system.

- On February 20, 1996, the Surinamese government informed the U.S. Embassy that it had taken the necessary steps to bring the investment incentive agreement (OPIC), signed in May of 1993, into force.

- Of Suriname's 100,000 labor force, roughly $50 \%$ are employed in the public sector. The labor force is generally well educated (literacy is over 90\%). However, Suriname has suffered from "brain drain" since independence in 1975.

- In addition to the official language, Dutch, most middle-class Surinamers are proficient in English.

- A license is no longer required to transfer profits and foreign currency out of the country, although currency regulations have been in flux since the Venetiaan administration began liberalizing regulations. Investors are advised to investigate the current situation. 


\section{Business Customs}

\section{Travel Advisory and Visas}

A passport and a visa are required for entry into the Republic of Suriname. Visas may be obtained at the Surinamese diplomatic and consular missions at 4310 Connecticut Avenue NW, Suite 108,

Washington, D.C.; or 7235 NW 19th Street, Suite A, Miami, FL (tourist visa only). Travelers staying more than eight days must register with the Vreemdelingendienst (Alien Service).

Travelers to Suriname's interior must note that there is insufficient police authority over much of the interior to offer assistance in an emergency. Isolated acts of violence, particularly in, but not limited to, the interior, do occur. Travelers to remote areas of the interior of Suriname should be aware that they might encounter difficulties because of the lack of government authority throughout the interior and inadequate medical facilities in some areas. The ability of the U.S. Embassy to assist in an emergency situation may be hampered by limited transportation and communications in some areas.

The rate of violent crime has increased, although it is still lower than most other countries in the region. Burglary and armed robbery are increasingly common in Paramaribo as well as in the outlying areas. Banditry occurs along routes in the interior where police protection is inadequate. Visitors may wish to exercise caution when traveling to the interior without an organized tour group and secure their belongings carefully while staying in Paramaribo.

\section{Business Infrastructure}

Business customs in Suriname do not differ significantly from those in the United States, although the pace can be a great deal more leisurely. Most businesses are open 8:00 a.m. to 4:30 p.m., Monday through Friday, and 8:00 a.m. to 1:00 p.m., on Saturday. In addition, some retail businesses extended their Friday evening hours until 7:00 p.m. Government offices generally are open 7:00 a.m. to 2:30 p.m. Meetings with government officials are best arranged in the morning. Government offices close early on Fridays and before holidays. Business entertainment largely takes place at dinners and cocktail parties. Business lunches do take place, but not on the same scale as in the United States. Working breakfasts are rare. Business suits are the norm, but semi-casual clothing is acceptable at most business meetings (except those with senior government officials). Surinamers prefer establishing a comfortable working relationship first, as opposed to directly tackling business. Given the consensual nature of the Surinamese government, there is often a lengthy consultation process before a decision is reached. Suriname is one hour ahead of Eastern Daylight Savings Time (two hours ahead of Eastern Standard Time). Driving is on the left-hand side of the road.

Suriname Airways (SLM), in conjunction with Dutch Caribbean Airways, operates service from Miami via Curacao. SLM also flies to Port of Spain, Georgetown, Barbados, Curacao, Cayenne, and Belem, where connections can be made with other airlines. Travelers to Suriname may experience disruptions in travel plans because of the unreliability of scheduled air service, both in international and interior flights. International flights are often overbooked and interior flights are often delayed, sometimes for days, because of mechanical difficulties, fuel shortages, and runway conditions. Suriname is also served by BWIA (via Trinidad) and Universal Airlines (from New York via

Georgetown). KLM and SLM provide joint service from Amsterdam.

Dutch is the official language of Suriname, but English is spoken by almost all likely business contacts. Other languages in common use are Sranan Tongo, Hindustani, Javanese, and some Portuguese.

Telephone and fax connections with the United States are good. Suriname is part of AT\&T's world connect service and USA direct. In addition, a number of callback companies have recently been established in Suriname. Internet access is possible via the state Telephone Company, Telesur, as well as through a private company.

Credit cards are rarely accepted, except at the larger hotels. In 1998, the largest commercial banks began offering Visa and MasterCard services. Still, business travelers are advised to bring traveler's checks or cash for expenses. 
Business travelers usually stay in one of the two large hotels in Paramaribo: the Hotel Torarica (telephone 597-471-500; fax 597-411-682) or the Hotel Krasnapolsky (telephone 597-475-050), although a number of other acceptable hotels are available. More informal accommodations are provided by Movement for Eco-Tourism in Suriname (METS), a major tour company offering guesthouses in Paramaribo as well as in the different districts. This company also offers eco-tourism tours to the interior.

Medical care is limited and does not meet U.S. standards. Malaria is not present in Paramaribo, but it is endemic in much of the interior. Overnight trips to certain sections of the interior require the use of malaria suppressants. Dengue fever is endemic throughout the country. Doctors and hospitals expect immediate, cash payments for access to health services, which are inexpensive when compared to U.S. facilities. Americans visiting Suriname who are injured or become ill during their visit will not be admitted to the only hospital with emergency and intensive care facilities unless they pay an advance deposit (payable only in U.S. Dollars) or provide proof of adequate insurance coverage in a form acceptable to the hospital. Business travelers should consult their health insurance company for information about reimbursement for medical expenses incurred outside the United Staes.

While water is generally potable in Paramaribo, visitors may wish to drink only bottled or boiled water to be on the safe side. Food in major hotels and leading restaurants is safe.

\section{Useful Web Sites}

\section{SURINAME:}

- US Embassy http:www.paramaribo.usembassy.gov

- American Chamber of Commerce (Suriname) http://www.amcham-suriname.org

- Suriname.net http://www.suriname.net
- USDA Foreign Agricultural Service http://www.fas.usda.gov

- US Export Programs Guide http://infoserv2.ita.doc.gov/ticwebsite/tic.nsf/ AF34FA880278BDD5825690D00656C6F/ F69FDCF72B7713B58525691900746F18?Open Document

- Internet Guide to Trade Leads http://infoserv2.ita.doc/gov/ticwebsite/tic.nsf/ 504ca249c786e20f85256284006da7ab/ ef7db94aef24919885266470049c1cd?OpenDocu ment

- US Trade Finance Resources http://infoserv2.ita.doc.gov/ticwebsite/tic.nsf/ AF34FA880278BDD5825690D00656C6F/ F69FDCF72B7713B58525691900746F18?Open Document

- Basic Guide to Exporting http://www.unzco.com/basicguide/index.html

\section{HEMISPHERIC:}

- Hemispheric Guide on Customs Procedures http://alca-ftaa.iadb.org/hgcp_eng.htm

- Hemispheric Trade and Tariff Database http://alca-ftaa.iadb.org/eng/ngmadb_e.htm

\section{UNITED STATES:}

